\title{
Financing Structure of Enterprises in the Metal Industry in Poland Between 2000 and 2010
}

\author{
Piotr Rzeszowski ${ }^{1}$ and Maria Sierpińska²
}

\begin{abstract}
This paper presents research results regarding the direction of changes in financing structure adopted by enterprises in the metal industry in Poland. This sector of industry is extremely important in Poland. The main reason for undertaking this research was a desire to gain insight into the problems that enterprises experience in finding financing sources during economic crises because banks restrict lending, profit declines, and the ability to utilize capital derived from stock exchanges is limited. The assessment was based on an analysis of the structure of financing sources and the relationship of credits to own capital and to liabilities. The structure of financing sources adopted by companies in the metal industry underwent significant changes between 2000 and 2010. Enterprises in this industry began to utilize own capital more often during the period, while the proportion of external capital to total liabilities decreased. The increase in the proportion of internal capital influenced the improvement in financial liquidity but also contributed to an increase in the average cost of capital and limited the range of profitable investments. The results validate initial research hypotheses regarding an increase in the participation of internal capital in the financing of enterprises' activities and a decrease in the amount of bank loans utilized by the companies.
\end{abstract}

KEY WORDS: $\quad$ financing structure, selection of financing sources, financial crisis

JEL Classification: G00

${ }^{1}$ Cracow University of Economics, Poland

${ }^{2}$ University of Finance and Management in Warsaw, Poland

\section{Introduction}

The development pace of enterprises and their market positions depend heavily on the availability of financing funds. Entities finance their activities with internal funds or with external funds. The relationship between internal capital and external capital is shaped by numerous factors that exert various influence on the entity, depending on the given economic situation. When the economy is in recession, companies generate much less profit and have restricted access to ex-

Corespondence concerning to this article should be addressed to: rzeszowskipiotrek@gmail.com ternal financing sources, which often leads to payment gridlocks where companies limit their development by refraining from investment. Several macro- and microeconomic factors that influence the structure of assets are enumerated in the literature on the subject. This paper elaborates on some of the significant factors in the metal industry, including the cost of capital, tax rates, availability of financing funds, timing of return on capital, stages of a company's life cycle, and financial and operational risk. Based on an analysis of financial structures, the direction of changes in these structures between 2000 and 2010 are evaluated, taking into account the boom period of the economic cycle (2004-2007) and the periods of recession in the 

fied amount of debt). Selection of the most suitable financing sources should be preceded by an in-depth analysis of a company's debt capacity. Debt capacity is the maximum amount of debt that a company may incur in ideal market conditions. It is usually associated with the possible bankruptcy of an enterprise. If optimal capital structure is tantamount to a maximized debt level, then a company should use only the optimal level of debt. Various theoretical models and practical methods adopted in American financial institutions have been developed for the purpose of determining a firm's debt capacity (Leibowitz, et al., 1990, p. 45).

Modern theories of capital structure demonstrate that a large number of factors play a role in determining the selection of financing sources. Several macroeconomic factors are recognized as highly significant, such as economic conditions, inflation, interest rates, tax rates, and other factors that may not be influenced by a company's managers but must be taken into account by them in choosing a source of financing. Specific economic situations can create uncertainty regarding the demand for products and their prices, the condition of the market in raw and other materials and fuels, changes in foreign exchange rates, and the tax system. The selection of financing sources is also highly influenced by interest rates (because they determine the cost of external capital) and tax rates, which affect the impact of a tax shield.

One of the most essential determinants in the selection of financing sources is the cost of capital. Generally, the cost of capital is the expected rate of return that participants in the market use as a basis to make their funds available for particular investment aims (Pratt \& Grabowski, 2008, p. 4). Developed market economies utilize the cost of capital not only to select financing sources but also in almost every other area of business life: buying and selling, evaluating assets, assessing alternative investment possibilities, evaluating health care services and tariffs for public utilities on the stock exchange, and many other areas (Pęksyk, Chmielewski \& Śledzik, 2010, p. 378).

Types of capital are characterized by the different costs incurred, and these differences allow enterprises to shape an optimal capital structure with the lowest possible cost. However, an enterprise's capital structure also affects the cost of its acquisition. This relationship is reciprocal. External capital can be cheaper than an enterprise's own capital because of the use of tax shields.

A tax shield is a benefit that a company enjoys because of a decrease in its tax burden. In determining the factors contributing to the shape of a capital structure, much attention has been devoted to non-interest tax shields, which are formed by depreciation and investment tax credits. DeAngelo and Masulis (1980, p. 14) have played an important role in research on the influence of non-interest tax shields on the capital structure of enterprises. They have shown that companies using large depreciation tax shields in relation to expected cash flows utilize less external capital to finance their activities.

Companies possess a fixed debt capacity that is dependent on the structure of their assets and the value of the companies' pledge that can be placed upon those assets. Especially in a period of economic slowdown, excessive debt may cause an enterprise to lose its financial liquidity because of a decrease in sales, which may lead to difficulty in settling interest liabilities and paying principal installments in a timely manner. Financial managers will therefore avoid financial risk by lowering the level of debt, and this approach will be reflected in the company's investment policy. Limitation of debt over a long period of time, however, may hinder the long-term development of the enterprise.

Moderate levels of debt, on the other hand, do not lead to a significant increase in risk and the simultaneous increase in the cost of an enterprise's own capital. However, shareholders tend to have higher expectations for rate of return on invested capital after a certain level of debt has been exceeded. This situation leads to an increase in the cost of an enterprise's own capital and the weighted average cost of capital (WACC). As risk increases, entities providing their own capital to an enterprise also expect a higher remuneration for their contributions. (Dudycz, 2005, p. 133).

Enterprises refrain from maximizing their level of debt because of the costs of bankruptcy. The literature on this subject indicates that the costs of financial uncertainty, referred to as the costs of bankruptcy, grow with an increase in the level of debt. The costs of bankruptcy include, inter alia: legal and administrative costs connected with liquidation proceedings, the costs from lost orders, and the costs related to the loss of clients' trust in the enterprise. Maintaining a certain 

threshold may be used as a means to measure this kind of risk. The higher the value of the profitability threshold, the more risk is involved in conducting business activities in a given sector. The level of operational risk also exerts influence over the scale of external financing sources for a company. Companies enjoying a low level of operational risk and a more stable operational environment often utilize debt financing to a greater extent than companies whose operations involve greater risk (Ostaszewski \& Cicirko, 2005, p. 146).

Financial risk refers to companies utilizing external financing sources and issuing preferential shares. Along with a growing level of debt, enterprises face the increased risk of a lack of funds to cover fixed financial costs such as interest, commissions, and margins on credits and long-term loans, as well as dividends on preferential shares. Financial risk rises as financial leverage increases. The benefits of financial risk can be measured by the difference between the profitability of an enterprise's own capital and the profitability of the total capital (Sierpińska \& Jachna, 2007, p. 311).

A company's ability to pay its liabilities on time is dependent on the length of the period of debt settlement because a company must adjust the structure of its financing sources to the structure of its possessed capital. For this reason, fixed assets should be largely financed from long-term financing sources, whereas current assets ought to be financed mainly from shortterm sources.

In conclusion, enterprises should strive toward an optimal capital structure that allows the maximum return on internal capital with concurrent preservation of financial liquidity and the capability to service their debt (Bień, 2002, p. 146). The optimum capital structure is achieved by finding a balance between the risk taken by an enterprise and the profit it generates. Appropriate selection of financing sources and their effective utilization contribute to the process of shaping an optimal capital structure. (Wilimowska \& Kopala, 2010, p. 447).

\section{Methodology of Research}

Research on the financing structures of economic entities operating in the metal industry in Poland was carried out with data derived from the Central Statistical Office of Poland. This sector is one of the most important in the country. Its assets constitute 12.7 per cent of Poland's industrial assets. Research on the financing structures of these economic entities focused on the period between 2000 and 2010. Three sub-periods have been singled out:

- sub-period between 2000 and 2003 - economic recession in Poland,

- sub-period between 2004 and 2007 - dynamic economic growth,

- sub-period between 2008 and 2010 - economic recession in Poland.

Estimations were separated for the metals production industry and the metal goods manufacturing (except for machines and devices) industry.

Analysis of the suitability of the financing structure to the structure of assets in the metal industry in the specified sub-periods was carried out by applying a liquidity criterion (i.e., the rate at which assets may be converted into liquid funds). In addition to compiling the indices on the financing structure of the companies, two other factors were measured: the relationship between credits and loans to total liability and the relationship between credits and loans to a company's own capital, which reflects the burden of the debt that this capital carries.

The sub-periods enumerated above provide a clear delineation of the changes that occurred in the financing structures of economic entities operating in the metal industry.

\section{Financing structure of enterprises in the metal industry}

Descriptions of the factors used in assessing the financing structures of economic entities in the Polish metal industry have been provided in the successive tables below. Table 1 presents the dynamics and structure of assets and financing sources of companies producing metals. The data indicate that the value of the assets of the entities decreased by almost 8 per cent during the first economic recession in 2001 and 2002. However, the assets then grew until 2008 before a decrease in value in 2009 was made up for in 2010. The assets appreciated relative to the previous year by over 13.3 per cent.

The structures of both assets and financing sources adopted by enterprises producing metals underwent profound changes between 2000 and 2010 (table 1). From 2000-2003, fixed assets dominated total assets. 
Table1. Dynamics and Structure of assets and liabilities in enterprises producing metals in Poland between the years 2000/2010, expressed in \%

\begin{tabular}{|c|c|c|c|c|c|c|c|c|c|c|c|}
\hline Year & 2000 & 2001 & 2002 & 2003 & 2004 & 2005 & 2006 & 2007 & 2008 & 2009 & 1010 \\
\hline Total assets in million PLN & 19489 & 17776 & 16378 & 19126 & 22580 & 23752 & 30255 & 36170 & 37748 & 33743 & 38238 \\
\hline $\begin{array}{l}\text { Dynamics, the previous year } \\
\text { equals }=100, \%\end{array}$ & 100.0 & 91.2 & 92.1 & 116.8 & 118.6 & 105.2 & 127.4 & 119.6 & 104.4 & 89.4 & 113.3 \\
\hline \multicolumn{12}{|c|}{ Structure, \% } \\
\hline Fixed assets & 65.7 & 68.0 & 65.0 & 67.3 & 54.8 & 55.7 & 53.7 & 51.7 & 55.9 & 61.7 & 55.5 \\
\hline Current assets & 34.3 & 32.0 & 35.0 & 32.7 & 45.2 & 44.3 & 46.3 & 48.3 & 44.1 & 33.3 & 44.5 \\
\hline Own capital & 29.3 & 19.6 & 8.8 & 24.8 & 40.8 & 44.3 & 49.4 & 52.1 & 50.4 & 52.0 & 54.9 \\
\hline Liabilities and reserves & 70.7 & 80.4 & 91.1 & 75.2 & 59.2 & 55.7 & 50.6 & 47.9 & 49.6 & 48.0 & 45.1 \\
\hline $\begin{array}{l}\text { Proportion of long-term liabilities } \\
\text { in total assets }\end{array}$ & 12.3 & 12.2 & 11.4 & 9.3 & 8.2 & 7.3 & 6.3 & 6.4 & 10.0 & 11.0 & 9.7 \\
\hline Constant capital & 41.6 & 31.8 & 20.2 & 34.1 & 49.0 & 51.6 & 55.7 & 58.5 & 60.4 & 63.0 & 64.6 \\
\hline
\end{tabular}

Note: Estimation carried out by the authors on the basis of data from the Central Statistical Office, "Bilansowe wyniki finansowe podmiotów gospodarczych 2000,2001,2002,2003,2004,2005,2006,2007,2008,2009,2010" [Financial Results of Economic Entities in 2000,2001,2002,2003,2004,2005,2006,2007,2008,2009,2010].

Fixed assets were 68 per cent of total assets in 2001 and decreased to 65 per cent the next year. Between 2004 and 2007, Polish companies underwent dynamic development, which contributed to changes in the structure of assets. Fixed assets amounted to 55 per cent of total assets in this period. The following economic recession was marked by another increase in the percentage of fixed assets to total assets. In 2010, the proportion of fixed assets to total assets was 55.5 per cent. Fluctuations in the structure of assets in companies engaged in the production of metals can be seen throughout the period. During a recession, the proportion of fixed assets to total assets grows; during a period of economic expansion, the structure of assets is more balanced. The presence of fixed assets, which are the basis for carrying out many vital processes, demonstrates a certain level of stability. As demand and sales decreases, so do current assets, which, in turn, leads to a decrease in their proportions in relation to total assets. Acceleration of the turnover of current assets improves the liquidity of economic entities.

The analysis of the amount of constant capital employed by companies for a period longer than one year shows that not until 2005 was its proportion enough to cover even half of the assets of this sector's enterprises. In 2006, constant capital outweighed fixed assets for the first time in the period. The following years show a gradual increase in the proportion of constant capital in relation to total capital, starting from 55.7 per cent in 2006 and increasing to 64.6 per cent in 2010, thus allowing the companies to maintain a positive value in net working capital. This result indicates an improvement in financial liquidity during the period, even through an economic recession. The increase in constant capital was achieved mainly through alterations in the financing structure of the enterprises. in this industry. Between 2000 and 2003, the assets were financed mainly with liabilities and reserves created for future liabilities. In the following years, the proportion of these liabilities and reserves in the financing structure amounted to $70.7 \%, 80.4 \%, 91.1 \%$, and $75.2 \%$. Meanwhile, internal capital constituted a rapidly increasing proportion of the structure of liabilities starting from 2004. It amounted to 24.8 per cent in 2003 but 40.8 per cent in 2004 and 54.9 per cent in 2010, which proves the hypothesis regarding the increase of internal capital in the financing structure of the enterprises.

The next question is whether the same tendencies are operative for the second part of the metal industry (i.e., for entities engaged in manufacturing metal goods). The data provided in table 2 allow the assess- 
ment of the dynamics and structure of assets and the sources of financing of these companies. The data show that the assets in this section of the industry are constantly growing. They decreased only in 2009 relative to the previous year but restored their level the next year with an increase of over 11 per cent. Characteristically, an increase in assets can be seen during the first economic recession between 2001 and 2003.

Table2. Dynamics and Structure of assets and liabilities in enterprises manufacturing metal goods in Poland between the years 2000/2010, expressed in \%

\begin{tabular}{|c|c|c|c|c|c|c|c|c|c|c|c|}
\hline Year & 2000 & 2001 & 2002 & 2003 & 2004 & 2005 & 2006 & 2007 & 2008 & 2009 & 2010 \\
\hline Total assets in million PLN & 12399 & 13052 & 14344 & 16769 & 18750 & 22579 & 28877 & 35766 & 40819 & 40506 & 45065 \\
\hline $\begin{array}{l}\text { Dynamics, the previous year } \\
\text { equals }=100, \%\end{array}$ & 100.0 & 105.3 & 109.9 & 116.9 & 111.8 & 120.4 & 127.9 & 123.8 & 114.1 & 99.2 & 111.2 \\
\hline \multicolumn{12}{|c|}{ Structure, $\%$} \\
\hline Fixed assets & 47.4 & 47.2 & 46.8 & 46.2 & 42.7 & 46.8 & 45.1 & 45.0 & 46.3 & 51.2 & 49.4 \\
\hline Current assets & 52.6 & 52.8 & 53.2 & 53.8 & 57.3 & 53.2 & 54.8 & 55.0 & 53.7 & 48.8 & 50.6 \\
\hline Own capital & 37.9 & 38.7 & 38.5 & 38.8 & 44.6 & 47.8 & 45.7 & 45.8 & 44.5 & 49.4 & 50.5 \\
\hline Liabilities and reserves & 62.1 & 61.3 & 61.5 & 61.2 & 55.4 & 52.2 & 54.3 & 54.2 & 55.5 & 50.6 & 49.5 \\
\hline $\begin{array}{l}\text { Proportion of long-term liabilities } \\
\text { in liabilities }\end{array}$ & 10.8 & 10.2 & 11.4 & 5.4 & 8.7 & 8.6 & 9.7 & 10.0 & 11.3 & 11.2 & 10.3 \\
\hline Constant capital & 48.7 & 48.9 & 49.9 & 44.2 & 53.3 & 56.4 & 55.4 & 55.8 & 55.8 & 60.6 & 60.8 \\
\hline
\end{tabular}

Note: Estimation carried out by the authors on the basis of data from the Central Statistical Office, "Bilansowe wyniki finansowe podmiotów gospodarczych 2000,2001,2002,2003,2004,2005,2006,2007,2008,2009,2010" [Financial Results of Economic Entities in $2000,2001,2002,2003,2004,2005,2006,2007,2008,2009,2010]$.

According to the data presented in table 2, the structure of assets for enterprises manufacturing metal goods is more stable than the structure for companies producing metals. Despite the financial crises during the period, there were no major fluctuations in the structure of assets for the metal goods manufacturers. During the first economic recession between 2001 and 2003, the tendency of fixed assets to grow in relation to total assets was not confirmed for this section of the industry. In fact, the proportion of fixed assets to total assets declined while the level of current assets increased. The same is true for the second economic recession in the period. The amount of fixed assets in relation to total assets increased from 45 per cent in 2007 to 49.4 per cent in 2010. Nevertheless, the clear tendency of fixed assets to grow in relation to total assets was visible for the whole sector in the period under analysis. This led to a proportional increase in the fixed cost of the maintenance of assets and had a negative impact on the financial results of the entities.
The proportion of internal capital in the financing structures consistently grew over almost the entire period. Internal capital amounted to 37.9 per cent in 2000 and 49.5 per cent in 2010 . The proportion of constant capital behaved in a similar manner; it was 48.7 per cent in 2000 and 59.7 per cent in 2010. Therefore, the hypothesis regarding the increase in internal capital in the financing structure of the metal industry is positively verified. Along with an increase in the proportion of own capital in relation to total liabilities, the level of constant capital also increased, which, in turn, improved the financial liquidity of the companies operating in this industry.

\section{Credits and loans as a source of financing for companies operating in the metal industry}

When the proportion of internal capital to overall financing sources increases, the level of debt is consequently lowered. This decline is especially apparent in the case of credits. An assessment of the utilization 
of credits by companies operating in the industry was performed based on the relationships between credits or loans and total liabilities and between credits or loans and own capital. The first relationship to be examined allows insight into the role of credits and loans in the structure of debt in enterprises. Taking out bank loans constitutes a traditional and relatively simple way of replenishing the financial resources of economic entities. However, taking out loans produces supplementary costs such as interest, margins, and commissions. Additionally, to use this form of external financing, an enterprise must have appropriate loan collateral and submit to various credit procedures. Credit scoring is the most important element of these procedures, and economic recession forces banks to make creditability requirements increasingly stringent. Because banks demand more collateral than usual, the participation of loans in the debt structure lowers. This interrelation can also be observed in the metal industry. When this industry is treated as a whole, it is apparent that the proportion of credits and loans to liabilities is reliant upon the given economic situation.

Table 3. Proportion of credits and loans in total liabilities in enterprises producing metals in Poland between the years 2000/2010

\begin{tabular}{lccccccccccc}
\hline Year & 2000 & 2001 & 2002 & 2003 & 2004 & 2005 & 2006 & 2007 & 2008 & 2009 & 2010 \\
\hline Total liabilities in million PLN & 12725 & 13254 & 13331 & 9973 & 9440 & 9404 & 11541 & 13738 & 15368 & 13252 & 14249 \\
Credits and loans in million PLN & 2708 & 2771 & 2620 & 2114 & 2611 & 2668 & 3516 & 4557 & 6131 & 4698 & 4819 \\
$\begin{array}{l}\text { Proportion of credits and loans in } \\
\text { total liabilities,\% }\end{array}$ & 21.3 & 20.9 & 19.6 & 21.2 & 27.7 & 28.4 & 30.5 & 33.2 & 40.0 & 35.4 & 33.8 \\
& & & & & & & & & & & \\
$\begin{array}{l}\text { Credits and loans in relation to } \\
\text { own capital }\end{array}$ & 47.4 & 79.5 & 181.0 & 44.6 & 28.3 & 25.3 & 23.5 & 24.2 & 32.2 & 26.8 & 22.9 \\
\hline
\end{tabular}

Note: Estimation carried out by the authors on the basis of data from the Central Statistical Office, "Bilansowe wyniki finansowe podmiotów gospodarczych 2000,2001,2002,2003,2004,2005,2006,2007,2008,2009,2010" [Financial Results of Economic Entities in $2000,2001,2002,2003,2004,2005,2006,2007,2008,2009,2010]$.

Table 4. Proportion of credits and loans in total liabilities in enterprises manufacturing metal goods in Poland between the years 2000/2010

\begin{tabular}{lccccccccccc}
\hline Year & 2000 & 2001 & 2002 & 2003 & 2004 & 2005 & 2006 & 2007 & 2008 & 2009 & 2010 \\
\hline Total liabilities in million PLN & 7004 & 7264 & 8046 & 8295 & 9530 & 10707 & 14309 & 17866 & 20888 & 18729 & 20500 \\
Credits and loans in million PLN & 1927 & 1883 & 2007 & 2241 & 3022 & 3584 & 4903 & 6368 & 8194 & 7099 & 6917 \\
$\begin{array}{l}\text { Proportion of credits and loans in } \\
\text { total liabilities,\% }\end{array}$ & 27.5 & 25.9 & 24.9 & 23.6 & 31.7 & 33.5 & 34.3 & 35.6 & 39.2 & 37.9 & 33.7 \\
& & & & & & & & & & & \\
$\begin{array}{l}\text { Credits and loans in relation to } \\
\text { own capital }\end{array}$ & 41.0 & 37.3 & 36.3 & 34.5 & 36.1 & 33.2 & 37.2 & 38.9 & 45.1 & 35.5 & 31.0 \\
\hline
\end{tabular}

Note: Estimation carried out by the authors on the basis of data from the Central Statistical Office, "Bilansowe wyniki finansowe podmiotów gospodarczych 2000,2001,2002,2003,2004,2005,2006,2007,2008,2009,2010" [Financial Results of Economic Entities in $2000,2001,2002,2003,2004,2005,2006,2007,2008,2009,2010]$. 
The proportion of loans to total liabilities declined between 2001 and 2003. However, from 2004 until 2008 , the proportion of credits or loans in the structure of debt increased by over 10 percentage points. It appears that this period of dynamic economic growth was propitious for this type of financing in the industry. The economic recession began in 2008, and its consequences on the debt structure are visible in the metal industry in 2009 and 2010, when the proportion of credits or loans to total liabilities decreased by about 6 percentage points. Thus, the hypothesis regarding a decrease in the amount of credit obligations utilized as financing sources by companies in the metal industry at the time of economic crises has been fully confirmed.

The second index provided in tables 3 and 4 shows the relationship of credit or loans to internal capital. It helps to determine whether there is an observable link between the proportion of credits and loans and the proportion of internal capital in a financing structure. The data show that the index of debt relevant for the entire metal industry decreased during the last financial crisis (other than 2008). The value of this index decreased by over 10 percentage points in 2010 compared to the year 2008. Consequently, as the proportion of credits or loans in the structure of liabilities declined, the proportion of internal capital increased, which validates the hypothesis regarding changes in the financing structure of companies in the metal industry. The fluctuations in this index are similar to the behavior of the index of a company's investment in internal capital. This leads to the conclusion that at a time of economic crisis companies are forced to finance their activities with their own capital, which increases this type of financing in the structure of liabilities. This is a result of the stricter policy of banks and the higher cost of external capital during a recession.

\section{Conclusion}

During an economic slowdown, companies must adopt a cautious approach toward the selection of capital for financing their activities. When their profit declines, obtaining capital by issuing shares is more difficult because the price of shares on the stock exchanges has decreased and credits are not readily available. Consequently, companies are more likely to employ own capital.

The aim of this research was to determine the direction of changes to the structure of financing sources of enterprises in the metal industry. The assessment was performed by analyzing the structure of financing sources and the relationship of credits to internal capital and to liabilities. The structure of financing sources adopted by companies in the metal industry underwent significant changes between 2000 and 2010. Enterprises in this industry began to utilize internal capital more often during the period while the proportion of external capital to total liabilities decreased. The changes in financing structures were caused by economic recessions that forced banks to adopt more stringent credit policies, making heavy reliance on bank loans impossible for many enterprises. This in turn led to a decrease in the proportion of credits and loans to total liabilities. Economic slowdowns also influenced the structure of assets of companies in the metal industry. The amount of fixed assets gradually increased in relation to total assets. Moreover, lower demand and fewer sales in these periods led to a decline in the value of current assets, decreasing the proportion of current assets to total assets.

The results validated the initial research hypotheses regarding an increase in the participation of internal capital in the financing of enterprises' activities and a decrease in the amount of bank loans utilized by the companies.

\section{References}

Bień, W. (2002). Zarządzanie finansami przedsiębiorstw [Management of a Company's Finances]. Warszawa: Difin.

Borkowska, I. (2007). Kryteria wyboru źródeł finansowania przedsiębiorstw $\mathrm{w}$ aspekcie metodologicznej racjonalności podejmowania decyzji finansowych [Criteria for Selecting Financing Sources in Companies in the Light of Methodological Rationality in Making Decisions on Finance]. In E. Urbańczyk (Ed.), Strategie wzrostu wartości przedsiębiorstwa [Strategies for Improving an Enterprise's Value], (pp. 207- 213). Szczecin: Uniwersytet Szczeciński.

DeAngelo, H., DeAngelo, L., Stulz, R. M. (2006). Dividend Policy and the Earning/Contributed Capital Mix: A Test of the Life-Cycle Theory. Journal of Financial Economics, 81(2), 227-254

DeAngelo, H., Masulis, R. W. (1980). Optimal Capital Structure under Corporate and Personal Taxation. Journal of Financial Economics, 8(1), 3-29. 
Dudycz, T. (2005). Zarządzanie wartościa przedsiębiorstwa [Management of the Value of a Company]. Warszawa: PWE.

Duliniec, A. (2007). Finansowanie przedsiębiorstwa. Strategie $i$ instrumenty [Financing Enterprises. Strategies and Instruments]. Warszawa: PWE.

Eldomiaty, T. I. (2007). Determinants of corporate capital structure: evidence from an emerging economy. International Journal of Commerce and Management, 17(1-2), 25-43.

Frielinghaus, A., Mostert, B., Firer, C. (2005). Capital structure and the firm's life stage. South African Journal of Business Management, 36(4), 9-18.

Gajdka, J. (2002). Teorie struktury kapitalu $i$ ich aplikacje $w$ warunkach polskich [Theories on Capital Structure and their Application in Polish Conditions]. Łódź: Wydawnictwo Uniwersytetu Łódzkiego.

Koller, T., Goedhart, M., Wessels, D. (2005). Valuation Measuring and Managing the Value of Companies. New Jersey, NJ: McKinsey and Company.

Min, Q. (2008). Prediction difficulty, financial strength and debt maturity. Journal of Modern Accounting and Auditing, 4(4), 14-22.

Leibowitz, M. L., Kogelman, S., Lindenberg, E. B. (1990). A Shortfall Approach to the Creditors Decision: How much Leverage can a Firm support? Financial Analysts Journal, 46(3), 43-52.

Ostaszewski, J. (2003). Zarządzanie finansami w spótce akcyjnej [Management of Finance in a Joint-Stock Company]. Warszawa: Difin.

Ostaszewski, J., Cicirko, T. (2005). Finanse spółki akcyjnej [Joint-Stock Company's Finance]. Warszawa: Difin.

Pęksyk, M., Chmielewski, M., Śledzik, K. (2010). Koszt kapitału a kryzys finansowy - przykład USA. [Cost of Capital vs. Financial Crisis - on the Example of the USA], Zarzadzanie Finansami. Inwestycje $i$ wycena przedsiębiorstw [Management of Finance. Investments and Evaluation of an Enterprise] (Zeszyty Naukowe Uniwersytetu Szczecińskiego, 586). Szczecin: Uniwersytet Szczeciński.

Pinegar, M. J., Wilbricht, L. (1989). What managers think of capital structure theory - a survey. Financial Management, 18(4), 82-91.

Pratt, S., Grabowski, R. (2008). Cost of Capital. Applications and Examples. New York, NY: Wiley.
Różański, J. (2008). Finansowanie a autonomia decyzyjna przedsiębiorstwa [Financing against $\mathrm{Au}-$ tonomy of Decision in Companies]. In B. Bernaś (Ed.) Zarządzanie Finansami Przedsiębiorstw- teoria i praktyka (Prace Naukowe Akademii Ekonomicznej im Oskara Langego we Wrocławiu nr 1200) (pp. 490-496). Wrocław: Wydawnictwo Akademii Ekonomicznej im Oskara Langego we Wrocławiu.

Sierpińska, M., Jachna, T. (2007). Metody podejmowania decyzji finansowych [Methods for Making Decisions on Finance]. Warszawa: WN PWN.

Wilimowska, Z., Kopala, K. (2010). Wpływ wybranych czynników na strukturę finansowa przedsiębiorstwa [Impact of Chosen Factors on the Financial Structure of Companies] (Zeszyty Naukowe Uniwersytetu Szczecińskiego, 26), Szczecin, Uniwersytet Szczeciński.

Zarzecki, D., Grudziński, M., Kisielewska, M. (2010). Wykorzystanie kapitałów obcych w finansowaniu przedsiębiorstw w Polsce [Utilisation of External Capital in Financing of Companies in Poland] (Zeszyty Naukowe Uniwersytetu Szczecińskiego, 586). Szczeciń, Uniwersytet Szczeciński. 